\title{
FEATURES OF THE INFLUENCE OF THE ENVIRONMENTAL FACTORS ON CARIES INCIDENCE AMONG THE POPULATION AGED 18 TO 24 IN THE CITY OF UZHGOROD AND UZHGOROD REGION Fera O.V., Kostenko Ye.Ya., Fera M.O., Kryvanych V.M., Sachuk A.S., Demchuk V.V., Kulesha T.O., Rusnak N.V., Chepara S.V. ВПЛИВУ ФАКТОРВВ ДОВКІЛЛЯ НА ЗАХВОРЮВАНІСТЬ СЕРЕД НАСЕЛЕННЯ ВІКОМ ВІД 18 ДО 24 РОКІВ М. УЖКГРОД І УЖГОРОДСЬКОМУ РАЙОН
}

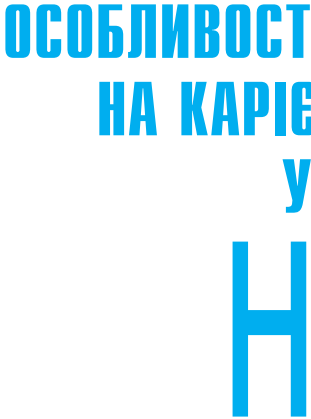

ФEPA O.B. КОСТЕНКО Є.Я., ФЕРА М.O.

КРИВАНИЧ В.М., САЧУК А.С. ДЕМЧУК В.В., КУЛЕША Т.О, PУCHAK H.B., ЧЕПАРА C.B.

Ужгородський національний університет

УДК : 616.314-002053.81(477.87):613

Ключові слова: фактори довкілля, стоматологічне захворювання, карієс, вікові

групи, населення ендемічного регіону. ині карієс зубів є найбільш поширеним стоматологічним захворюванням серед населення України. Тенденції розвитку захворюваності залишаються негативними протягом останніх десяти років у зв'язку з дією низки несприятливих факторів [1, 2, 4].

Здоров'я людини залежить від багатьох факторів. Такий стан організму не можна розглядати, як щось автономне, пов'язане тільки з індивідуальними особливостями. Воно $€$ наслідком впливу соціальних і природних чинників $[1,8,9]$. Вважається, що спосіб життя приблизно на 50\% визначає здоров'я: умови праці, харчування, матеріально-побутові умови, взаємовідносини у сім'ї тощо. На 20\% здоров'я залежить від генетичного фактора, на 20\% - від стану природного середовища і лише на 10\% - від рівня та якості медичного обслуговування населення. Темпи індустріалізації й урбанізації за певних умов можуть призвести до порушення екологічної рівноваги між довкіллям та населенням, викликати деградацію середовища і здоров'я населення. Тому здоров'я і хвороби відображатимуть стан довкілля $[6,10]$.

Карієс серед інших стоматологічних захворювань складає близько 85\% [3,
8]. Проблема профілактики карієсу зубів, незважаючи на значну кількість вітчизняних та зарубіжних праць, і нині залишається актуальною. Особливу увагу стоматолога привертає поверхневий карієс зубів [5]. Лікування карієсу на цій стадії сприяє відновленню анатомічної форми зубів, їхньої функції та дає змогу запобігти подальшому розвитку каріозного процесу, зупинити його ускладнення.

Закарпатська область $€$ ендемічною зоною і характеризується дефіцитом багатьох мікроелементів, які зумовлюють виникнення захворювань, зокрема стоматологічних.

Метою проведення даного дослідження $€$ визначення зв'язків факторів довкілля 3 захворюванням на карієс серед населення віком від 18 до 24 років м. Ужгород і Ужгородського району та визначення частоти прояву захворювання на карієс внаслідок впливу факторів навколишнього середовища.

Матеріали та методи дослідження: ми проводили анкетування населення відповідних вікових груп, аналіз первинної стоматологічної документації. Отримані результати піддавали математично-статистичній обробці.
ОСОБЕННОСТИ ВЛИЯНИЯ ФАКТОРОВ ОКРУЖАЮЩЕЙ СРЕДЫ НА ЗАБОЛЕВАЕМОСТЬ КАРИЕСОМ СРЕДИ НАСЕЛЕНИЯ В ВОЗРАСТЕ ОТ 18 ДО 24 ЛЕТ В Г. УЖГОРОД И УЖГОРОДСКОМ РАЙОНЕ Фера А.В., Костенко Е.Я., Фера М.А. Криванич В.М., Сачук А.С., Демчук В.В., Кулеша Т.А., Руснак Н.В., Чепара С. В. Ужгородский национальный университет

На основании изучения факторов окружающей среды и закономерностей их влияния на развитие кариозного процесса были получены данные по распространению кариеса среди населения г. Ужгорода и Ужгородского района. Анализ результатов анкетирования и математико-статистической обработки позволил выявить факторы, которые имеют наиболее существенное влияние на возникновение и развитие кариеса: несоблюдение правил личной гигиены, наследственная предрасположенность, частота чистки зубов, несоблюдение правил гигиены полости рта, вредные привычки, вид водоснабжения.

Ключевые слова: факторы окружающей среды, стоматологическое заболевание, кариес, возрастные группы, население эндемического региона.
FEATURES OF THE INFLUENCE OF THE ENVIRONMENTAL FACTORS ON CARIES INCIDENCE AMONG THE POPULATION AGED 18 TO 24 IN THE CITY OF UZHGOROD AND UZHGOROD REGION

Fera O.V., Kostenko Ye. Ya., Fera M.O., Kryvanych V.M., Sachuk A.S., Demchuk V.V., Kulesha T.O., Rusnak N.V., Chepara S.V. Uzhgorod National University, Ukraine

On the basis of the study of the environmental factors and the patterns of their impact on the development of caries process we obtained the data on the prevalence of caries among the population of the city of Uzhgorod and Uzhgorod region. Analysis of the results of survey and mathematical-statistical processing made it possible to identify the factors that affected the most significantly the occurrence and the development of caries: non-observance of personal hygiene rules, genetic predisposition, frequency of teeth cleaning, non-observance of the rules of oral cavity hygiene, bad habits, type of water supply.

Keywords: environmental factors, dental disease, caries, age groups, population of endemic region.

() Фера О.В., Костенко Є.Я., Фера М.О., Криванич В.М., Сачук А.С., Демчук В.В., Кулеша Т. О, Руснак Н.В., Чепара С.В. СТАТТЯ, 2017. 
Результати та їх обговорення. У ході дослідження було проведено аналіз зв'язків факторів довкілля з захворюванням на карієс у жителів м. Ужгород і Ужгородського району віком від 18 до 24 років.

\begin{tabular}{|l|c|c|}
\hline Стать / вік & $\begin{array}{c}\text { К-сть } \\
\text { анкет за } \\
\text { віком i } \\
\text { статтю }\end{array}$ & $\begin{array}{c}\text { Загальна } \\
\text { кількість } \\
\text { анкет }\end{array}$ \\
\hline Чол. 18-20 р. & 45 & 205 \\
\hline Жін. 18-20 р. & 56 & \\
\hline Чол. 21-24 р. & 53 & \\
\hline Жін. 21-24 р. & 51 & \\
\hline
\end{tabular}

Ми визначали 30 факторів: ПІБ, вік, місце проживання, розташування житла, вид помешкання, район розташування житла, рівень вологості місця проживання, наявність домашніх тварин, рівень освіти, рівень прибутку, шкідливі звички, частота прийомів їжі на день, кількість перекусів протягом дня, тип харчування, вид продуктів харчування у щоденному раціоні, кількість вітамінів у добовому раціоні, кількість спожитої води протягом дня, вид спожитої води, вид водопостачання, контакт з ґрунтом, контакт з агресивними хімічними речовинами, геліометеотропна чутливість, тривалість сну, частота стресових ситуацій, дотримання правил особистої гігієни, спадкова схильність до захворювання, інфекційні та вірусні захворювання, дотримання правил гігієни ротової порожнини, частота чищення зубів, механічна травма щлД.

Т-критерій Ст'юдента має найбільше значення для таких факторів:

口 серед чоловіків віком 18-20 років - «вид водопостачання» $\mathrm{t}=2.35$; «дотримання правил особистої гігієни» $t=1.98$; «шкідливі звички» $\mathrm{t}=1.99$; «частота чищення зубів» $t=2$; «спадкова схильність до захворювання» $\mathrm{t}=1.98$; «рівень прибутку» $\mathrm{t}=$ 2.25 ; «дотримання правил гігієни ротової порожнини» $\mathrm{t}=2,23$;

$\square$ серед жінок віком 18-20 років - «частота чищення зубів» $\mathrm{t}=$ 2.71; «розташування житла» $t=$ 1.99; «частота прийомів їжі на день» $\mathrm{t}=2.37$; «вид водопостачання» $\mathrm{t}=2.21$; «геліометеотропна чутливість» $\mathrm{t}=2.07$; « дотримання правил особистої гігієни» $\mathrm{t}=1.98$; «дотримання правил гігієни ротової порожнини» $\mathrm{t}=2.36$;

$\square$ серед чоловіків віком 21-24 роки - «дотримання правил особистої гігієни» $\mathrm{t}=2.36$; «місце проживання» $t=2.33$; «шкідливі

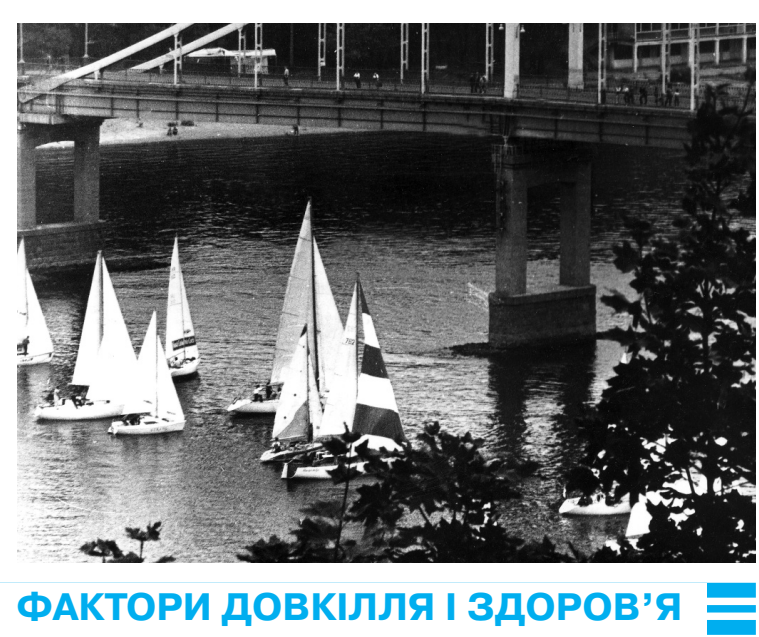

звички» $t=2.21$; «вид водопостачання» $t=2.27$; «геліометеотропна чутливість» $t=2,17$; «перенесені інфекційні та вірусні захворювання» $\mathrm{t}=1.99$; «дотримання правил гігієни ротової порожни-

ни» $\mathrm{t}=2.19$; «частота чищення зубів» $t=2.16$;

口 серед жінок віком 21-24 роки - «спадкова схильність» $\mathrm{t}=$ 2.31; «місце проживання» $\mathrm{t}=$ 2.13; «тип харчування» $\mathrm{t}=2.45$;

Таблиця 1

Вплив факторів навколишнього середовища на розвиток карієсу за коефіцієнтом Ст'юдента (серед населення віком від 18 до 24 років)

\begin{tabular}{|l|c|c|c|c|}
\hline \multirow{2}{*}{\multicolumn{1}{|c|}{ Фактор впливу }} & \multicolumn{4}{|c|}{ Карієс } \\
\cline { 2 - 5 } & \multicolumn{1}{|c|}{$18-20$ р. } & \multicolumn{2}{|c|}{$21-24$ р. } \\
\cline { 2 - 5 } & 4 & Ж & 4 & Ж \\
\hline Місце проживання & 1,67 & 1,18 & 2,33 & 2,13 \\
\hline Розташування житла & 1,38 & 1,99 & 1,10 & 1,38 \\
\hline Рівень прибутку & 2,25 & 0,78 & 1,55 & 0,04 \\
\hline Куріння, вживання алкоголю & 1,99 & 1,73 & 2,2100 & 1,39 \\
\hline Частота прийомів їжі на день & 1,01 & 2,37 & 0,41 & 0,71 \\
\hline Тип харчування & 0,66 & 0,18 & 0,71 & 2,45 \\
\hline К-сть спожитої води протягом дня & 1,70 & 1,80 & 1,30 & 1,98 \\
\hline Вид водопостачання & 2,35 & 2,21 & 2,27 & 2,24 \\
\hline Геліометеотропна чутливість & 0,91 & 2,07 & 2,17 & 1,35 \\
\hline Дотримання правил особистої гігієни & 1,98 & 1,98 & 2,36 & 1,99 \\
\hline Спадкова схильність до захворювання & 1,98 & 0,80 & 1,46 & 2,31 \\
\hline Інфекційні та вірусні захворювання & 0,17 & 1,87 & 1,99 & 1,07 \\
\hline Дотримання гігієни ротової порожнини & 2,23 & 2,36 & 2,19 & 1,99 \\
\hline Частота чищення зубів & 2,00 & 2,71 & 2,16 & 2,56 \\
\hline
\end{tabular}

Рисунок 1

Вплив факторів довкілля на розвиток карієсу за коефіцієнтом Ст'юдента (серед населення віком від 18 до 20 років)

口Kapiec 18-20 p. ५ ¿Kapiec 18-20 p. $ж$
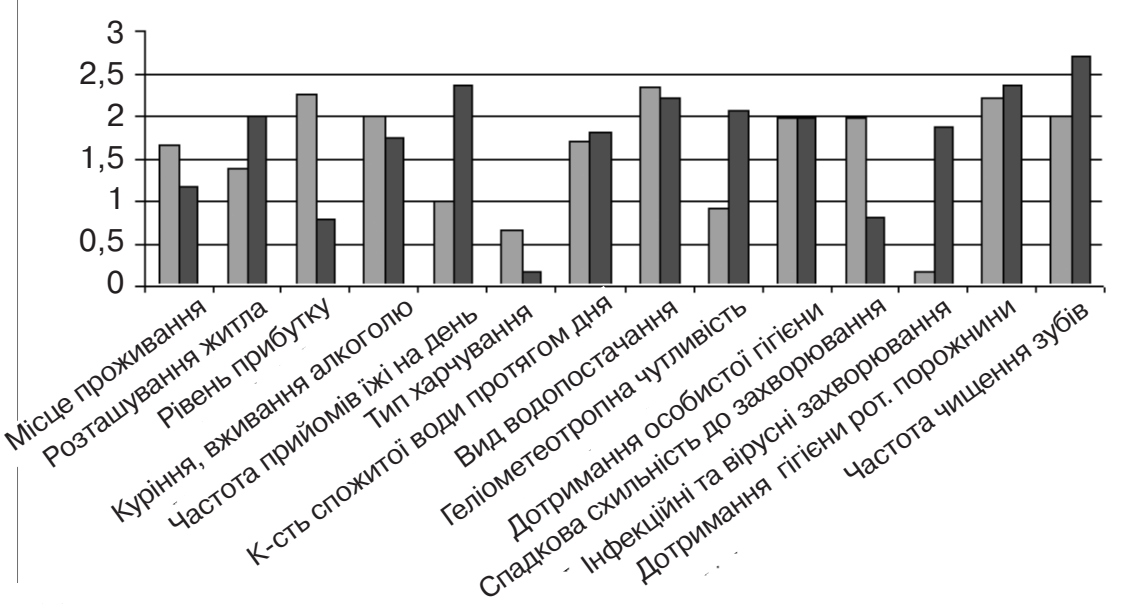
«кількість спожитої води протягом дня» $\mathrm{t}=1.98$; «вид водопостачання» $\mathrm{t}=2.24$; «дотримання правил особистої гігієни» $\mathrm{t}=$ 1.99; «дотримання правил гігієни ротової порожнини» $\mathrm{t}=1.99$; «частота чищення зубів» $t=2.56$.

Спільними факторами за

впливом на формування карієсу серед населення досліджуваних нами груп за віком та статтю $є$ дотримання правил гігієни ротової порожнини $\left(\mathrm{t}_{\text {середнє }}=\right.$ $2,19)$, частота чищення зубів $\left(\mathrm{t}_{\text {середнє }}=2,36\right) ;$ дотримання

Рисунок 2

Вплив факторів довкілля на розвиток карієсу за коефіцієнтом Ст'юдента (серед населення віком від 21 до 24 років)

口 Kapiec 21-24 p. 4 ㅈapiec 21-24 p. $*$
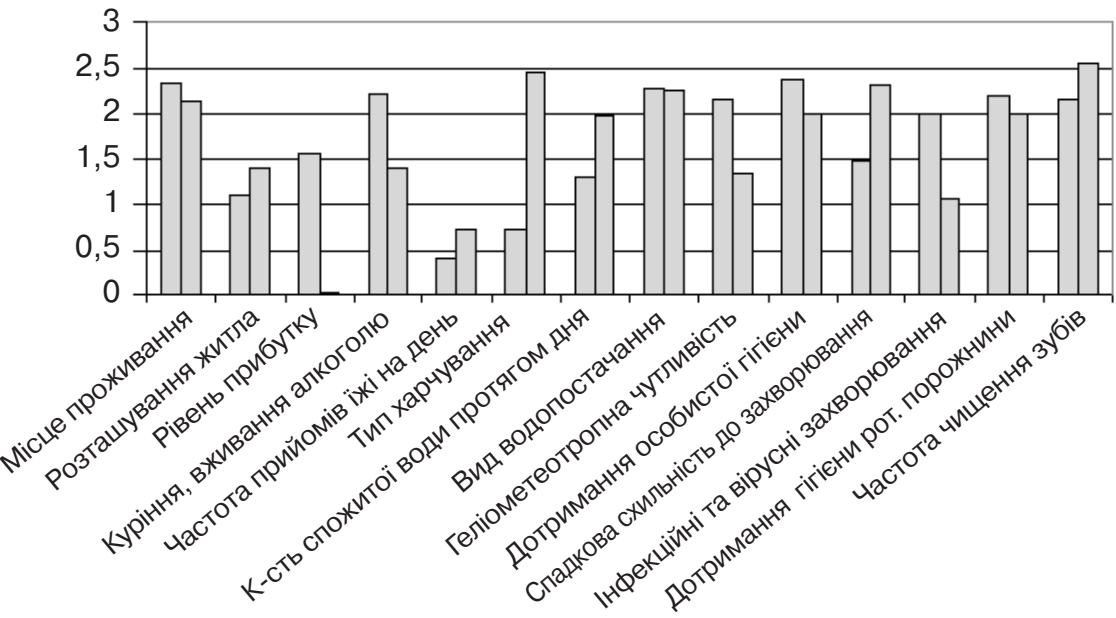

Таблиця 2

Вплив факторів навколишнього середовища на розвиток карієсу за коефіцієнтом рангової кореляції Спірмена (серед населення віком від 18 до 24 років)

\begin{tabular}{|l|c|c|c|c|}
\hline \multirow{2}{*}{ Фактор впливу } & \multicolumn{4}{|c|}{ Kapiєс } \\
\cline { 2 - 5 } & \multicolumn{2}{|c|}{$18-20$ р. } & \multicolumn{2}{|c|}{$21-24$ р. } \\
\cline { 2 - 5 } & 4 & Ж & 4 & ж \\
\hline Куріння, вживання алкоголю & 0,87 & 0,95 & 0,93 & 0,84 \\
\hline Частота прийомів їжі на день & 0,32 & 0,88 & 0,21 & 0,4 \\
\hline Тип харчування & 0,13 & 0,42 & 0,97 & 0,91 \\
\hline Дотримання правил особистої гігієни & 0,93 & 0,73 & 0,71 & 0,88 \\
\hline Дотримання гігієни рот. порожнини & 0,91 & 0,84 & 0,87 & 0,93 \\
\hline Частота чищення зубів & 0,97 & 0,95 & 0,83 & 0,9 \\
\hline
\end{tabular}

Вплив факторів довкілля на розвиток карієсу за коефіцієнтом рангової кореляції Спірмена (серед населення віком від 18 до 20 років)

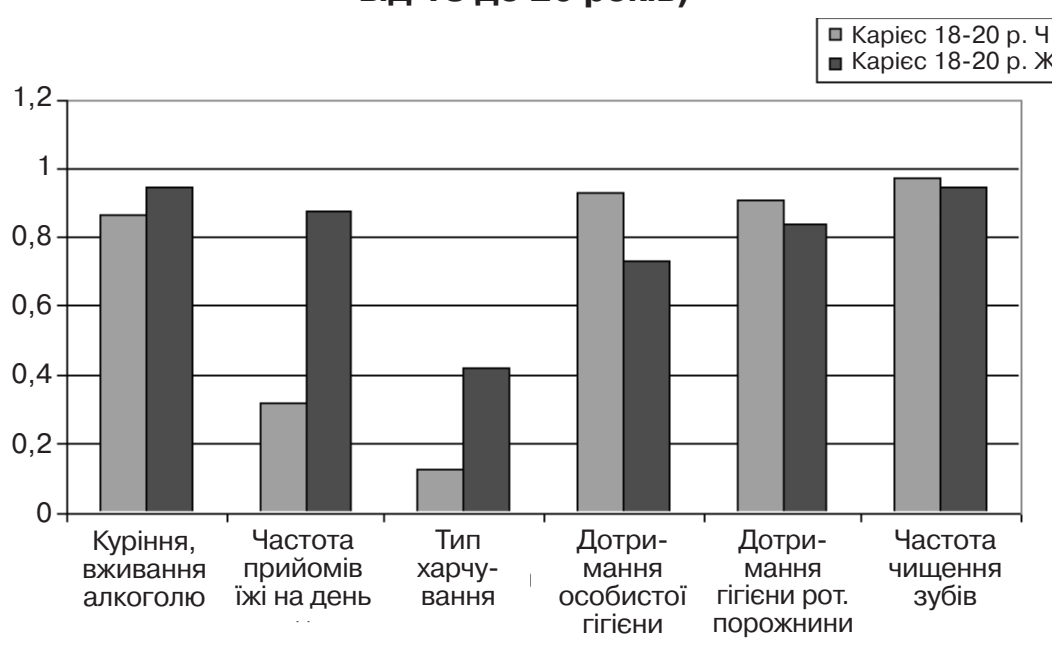

правил особистої гігієни $\left(\mathrm{t}_{\text {середне }}=2,07\right)$; вид водопостачання ( $\left.\mathrm{t}_{\text {середнє }}=2,27\right)$.

Для визначення оцінки рівня впливу факторів навколишнього середовища на розвиток карієсу було взято коефіцієнт рангової кореляції Спірмена.

Отже, найбільший зв'язок було виявлено з такими чинниками:

口 серед чоловіків віком 18-20 років - «частота чищення зубів» $r=0,97$; «дотримання правил особистої гігієни» $r=0,93$; «шкідливі звички» $r=0.87$; «дотримання правил гігієни ротової порожнини» $r=0.91$;

с серед жінок віком 18-20 років - «шкідливі звички» $r=0,95$; «частота прийомів їжі на день» $r=$ 0.88 ; «частота чищення зубів» $r=$ 0,95; «дотримання правил гігієни ротової порожнини» $r=0.84$

口 серед чоловіків віком 21-24 роки - «тип харчування» $r=0,97$; «шкідливі звички» $r=0,93$; «частота чищення зубів» $r=0,83$; «дотримання правил гігієни ротової порожнини» $r=0.87$;

口 серед жінок віком 21-24 роки - «тип харчування» $r=0,91$; «частота чищення зубів» $r=0,9$; «дотримання правил гігієни ротової порожнини» $r=0.93$; «дотримання правил особистої гігієни» $r=0.88$; «шкідливі звички» $r=0.84$.

Факторами, які $є$ спільними для усіх досліджуваних груп, що зумовлюють виникнення карієсу, $€$ «частота чищення зубів» $r_{\text {середне }}=0,91$; «шкідливі звички» $r$ середнє $=0.89$; «дотримання правил гігієни ротової порожнини» $r=0.89$.

Для виявлення достовірності результатів ми визначали вплив факторів довкілля на розвиток карієсу за коефіцієнтом лінійної кореляції Пірсона.

Найбільший зв'язок було виявлено з такими факторами:

$\square$ серед чоловіків віком 18-20 років - «місце проживання» $p=$ 0.81 ; «шкідливі звички» $p=0.81$; «кількість спожитої води протягом дня» $\mathrm{p}=0.91$; «спадкова схильність до захворювання» $\mathrm{p}=$ 0.86; «дотримання правил гігієни ротової порожнини» $\mathrm{p}=0.82$; «частота чищення зубів» $p=0.86$;

с серед жінок віком 18-20 років - «шкідливі звички» $\mathrm{p}=$ 0.91; «вид водопостачання» $p=$ 0,87 ; «спадкова схильність до захворювання» $\mathrm{p}=0.83$; «дотри мання правил гігієни ротової порожнини» $\mathrm{p}=0.83$; «частота чищення зубів» $p=0.92$;

серед чоловіків віком 21-24 роки - «місце проживання» $\mathrm{p}=$ 0.88; «шкідливі звички» $p=0.93$; «тип харчування» $p=0.92$; «ге- 
ліометеотропна чутливість» $\mathrm{p}=$ 0.92; «спадкова схильність до захворювання» $p=0,9$; «дотримання правил гігієни ротової порожнини» $\mathrm{p}=0.99$; «частота чищення зубів» $p=0.88$;

$\square$ серед жінок віком 21-24 роки - «місце проживання» $\mathrm{p}=$ 0.91; «шкідливі звички» $p=0.82$; «кількість спожитої води протягом дня» $p=0.97$; «спадкова схильність до захворювання» $\mathrm{p}=$ 0.93; «дотримання правил гігієни ротової порожнини» $\mathrm{p}=0.87$; «частота чищення зубів» $\mathrm{p}=0.96$.

Спільними факторами за впливом на формування карієсу серед населення досліджуваних нами груп за віком та статтю $€$ «частота чищення зубів» рередне $_{\text {с }}=$ 0,9; «шкідливі звички» $p_{\text {середне }}=$ 0,87 ; «спадкова схильність до захворювання» $p_{\text {середнє }}=0,88$; «дотримання правил гігієни ротової порожнини» $p_{\text {середнє }}=0,88$.

У ході досліджень було встановлено зв'язок між розвитком карієсу та факторами, що впливають на нього. Провівши математичний аналіз даних анкетування, ми визначили чинники, які найбільше впливають на виникнення та поширення карієсу.

У групі чоловіків віком 18-20 років факторами, які найбільш суттєво впливають на виникнення карієсу, на підставі розрахованих коефіцієнтів Ст'юдента та рангової кореляції Спірмена $є$ дотримання правил особистої гігієни ( $t=1.98 ; r=0.93)$, шкідливі звички ( $t=1.99 ; r=0,87)$, частота чищення зубів $(t=2 ; r=0,97)$, спадкова схильність до захворювання ( $t=1.98 ; r=0,78)$, рівень прибутку ( $\mathrm{t}=2.25 ; \mathrm{r}=0.67)$, водопостачання ( $\mathrm{t}=2.35 ; \mathrm{r}=0.77$ ), дотримання правил гігієни ротової порожнини ( $t=2,23 ; r=0,91)$.

У групі жінок віком 18-20 років факторами, які найбільше впливають на виникнення карієсу, за показниками коефіцієнтів Ст'юдента та рангової кореляції Спірмена є розташування житла ( $\mathrm{t}=1.99 ; r=0,59)$, частота прийомів їжі ( $t=2.13 ; r=0,88)$, геліометеотропна чутливість $(\mathrm{t}=$ $2.07 ; r=0,69)$, ендемічна зона $(t=2.21 ; r=0.55)$, дотримання правил особистої гігієни ( $\mathrm{t}=$ $1.98 ; r=0.73)$, частота чищення зубів ( $t=2.71 ; r=0.95)$, дотримання правил гігієни ротової порожнини ( $t=2.36 ; r=0,84)$.

У групі чоловіків віком 21-24 років факторами, які найбільш суттєво впливають на виникнення карієсу, на підставі розрахованих коефіцієнтів Ст'юдента та рангової кореляції Спірмена $€$ місце проживання $(\mathrm{t}=2.33 ; \mathrm{r}=$ 0,67), дотримання правил особистої гігієни $(t=2.36 ; r=0.71)$, частота чищення зубів $(t=2.16 ; r$ $=0,83$ ), геліометеотропна чутливість ( $t=2.17 ; r=0,75)$, перенесені інфекційні та вірусні захворювання ( $t=1.99 ; r=0,74)$, водопостачання ( $\mathrm{t}=2.27 ; r=0,51$ ), дотримання правил гігієни ротової порожнини $(t=2,19 ; r=0.87)$.

У групі жінок віком 21-24 років факторами, які найбільше впливають на виникнення карієсу, на підставі розрахованих коефіцієнтів Ст'юдента та рангової кореляції Спірмена $€$ кількість спожитої води протягом дня $(\mathrm{t}=$ $1.98 ; r=0,77)$, тип харчування ( $t$ $=2.45 ; r=0.91)$, частота чищення зубів ( $t=2.56 ; r=0,9)$, спадкова схильність до захворювання на карієс $(t=2.31 ; r=0.67)$, водопостачання $(\mathrm{t}=2.24 ; \mathrm{r}=$

\section{Вплив факторів довкілля на розвиток карієсу за коефіцієнтом рангової кореляції Спірмена (серед населення віком від 21 до 24 років)}

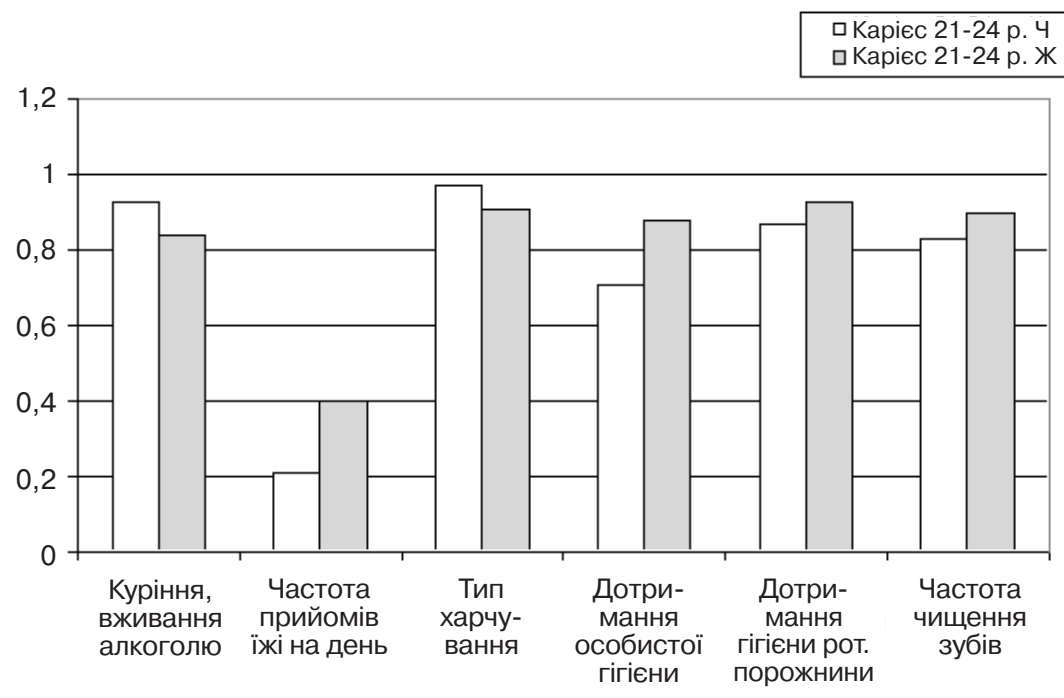

Таблиця 3

Вплив факторів навколишнього середовища на розвиток карієсу за коефіцієнтом лінійної кореляції Пірсона (серед населення віком від 18 до 24 років)

\begin{tabular}{|l|c|c|c|c|}
\hline \multirow{2}{*}{ Фактор впливу } & \multicolumn{4}{|c|}{ Карієс } \\
\cline { 2 - 5 } & \multicolumn{2}{|c|}{$18-20$ р. } & \multicolumn{2}{|c|}{$21-24$ р. } \\
\cline { 2 - 5 } & 4 & Ж & 4 & Ж \\
\hline Місце проживання & 0,81 & 0,29 & 0,88 & 0,91 \\
\hline Шкідливі звички & 0,81 & 0,91 & 0,93 & 0,82 \\
\hline Тип харчування & 0,31 & 0,79 & 0,92 & 0,63 \\
\hline К-сть спожитої води протягом дня & 0,91 & 0,33 & 0,75 & 0,97 \\
\hline Вид водопостачання & 0,54 & 0,87 & 0,37 & 0,48 \\
\hline Геліометеотропна чутливість & $-0,22$ & 0,54 & $-0,26$ & 0,72 \\
\hline Дотримання правил особистої гігієни & 0,71 & 0,43 & 0,62 & 0,76 \\
\hline Спадкова схильність до захворювання & 0,86 & 0,83 & 0,9 & 0,93 \\
\hline Дотримання гігієни рот. порожнини & 0,82 & 0,83 & 0,99 & 0,87 \\
\hline Частота чищення зубів & 0,86 & 0,92 & 0,88 & 0,96 \\
\hline
\end{tabular}

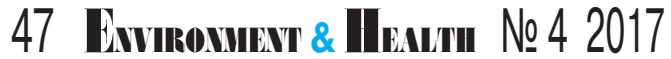


$r=0,9)$, недотримання правил гігієни ротової порожнини $(\mathrm{t}=$ $2,19 ; r=0.87)$, шкідливі звички $(\mathrm{t}=1.99 ; r=0,95)$, вид водопостачання $(t=2.24 ; r=0.61)$.

3. Встановлено також фактори, які не мають суттєвого впливу або взагалі не впливають на розвиток карієсу: контакт з ґрунтом ( $t=0,61 ; r=0.18)$, кількість спожитої води $(t=1,3 ; r=$ $0,2)$, наявність домашніх тварин $(\mathrm{t}=0,88 ; r=0,3)$, тривалість сну $(\mathrm{t}=0,7 ; r=0,1)$.

4. Для зниження показників захворюваності на карієс серед населення різних вікових груп необхідно мінімізувати вплив факторів ризику та запровадити заходи первинної профілактики карієсу.

ЛІТЕРАТУРА

1. Фера А.В., Лучкевич В.С., Захарченко М.П. Окружающая середа и здоровье населения. Ужгород, 2002. 284 с.

2. Боровский Е.В., Иванов В.С., Максимовский Ю.М., Макси- мовская Л.Н. Терапевтическая стоматология.

Москва, 1998

3. Лукиных Л.М. Кариес зубов (этиология, клиника, лечение, профилактика) : монография. Нижний Новгород, 1999. 185 с

4. Данилевський М.Ф., Борисенко А.В., Полігун А.М., Сідельнікова Л.Ф., Несин О.Ф. та ін. Терапевтична стоматологія. Київ : Здоров'я, 2010. Т. 2. 407с 5. Борисенко А.В. Кариес зубов. Практическое руководство.

Киев : Книга плюс, 2000. 342 с.

6. Практикум з терапевтичної стоматології / за ред. А.В. Борисенка. Київ : Книга-плюс, 2011.

7. Лангле Р.П., Миллер К.С. Атлас заболеваний полости рта. - пер. с англ. М. : ГЭОТАРМедиа, 2008. 80 с.

8. Лобанов С.A. Как сохранить здоровые зубы. Профилактика основных стоматологических заболеваний. СПб : Нева ; М. : ОЛМА-ПРЕСС Экслибрис, 2003 41-57 c.

Рисунок 5

Вплив факторів навколишнього середовища на розвиток карієсу за коефіцієнтом лінійної кореляції Пірсона (серед населення віком від 18 до 20 років)

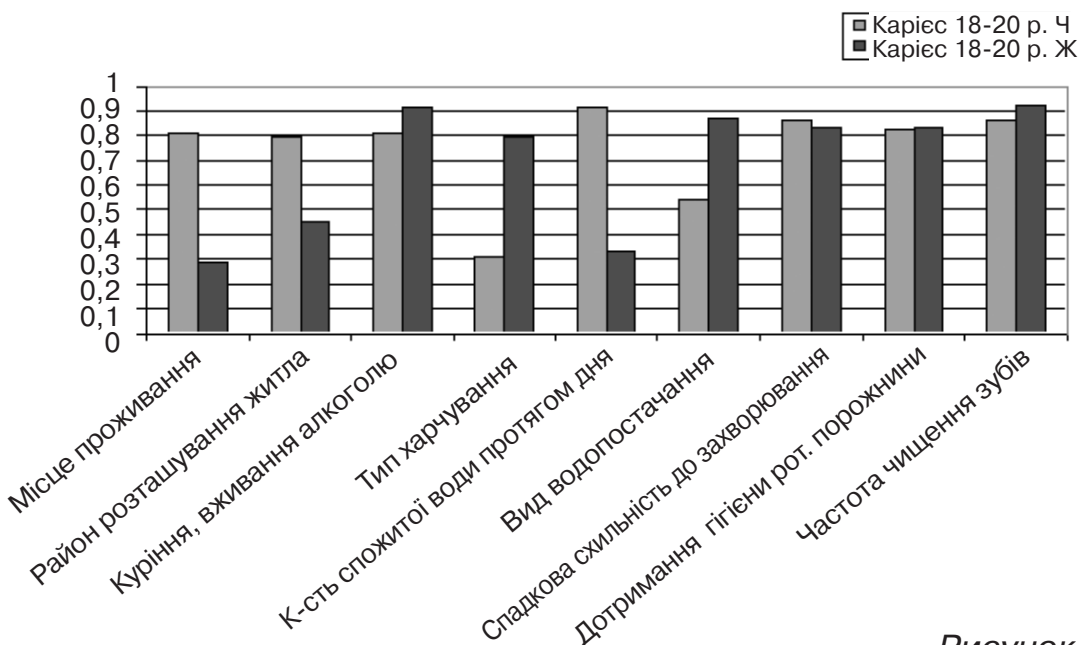

Рисунок 6

Вплив факторів навколишнього середовища на розвиток карієсу за коефіцієнтом лінійної кореляції Пірсона (серед населення віком від 21 до 24 років)

口 Kapiec 21-24 p. 4 К Kapiec 21-24 p. Ж

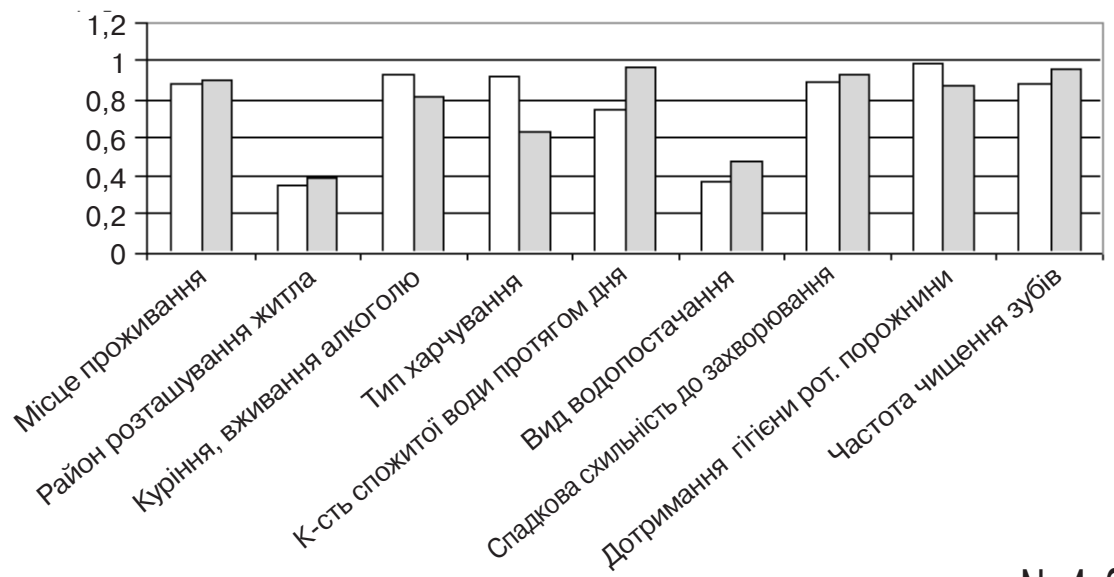

9. Сердюк А.М. Екологічна безпека: гігієнічний погляд через роки. Мед. перспективи. 2007. № 4. С. 4-7.

10. Бердник О.В., Зайковська В.Ю., Сидоренко Т.П., Добрянська О.В. Імовірнісний підхід до прогнозування відхилень у здорових дітей. Biomedical and Biosocial Anthropology. 2009.

Вип. 2. № 13. С. 12-14.

\section{REFERENCES}

1. Fera A.V., Luchkevich V.S. and Zakharchenko M.P. Okruzhaiushchaia sreda I zdorovie naseleniia [Environment and Health of the Population]. Uzhgorod (Ukraine) ; 2002 : 284 p. (in Russian).

2. Borovskiy Ye.V., Ivanov V.S., Maksimovskiy Yu.M. and Maksimovskaya L.N. Terapevticheskaya stomatologiya : uchebnik [Therapeutic Dentistry : Manual]. Moscow ; 1998 (in Russian).

3. Lukinykh L.M. Karies zubov (etiologiya, klinika, lechenie, profilaktika) : monografiia [Dental Caries (Etiology, Clinic, Treatment, Prophylaxis) : Monograph]. Nizhniy Novgorod (Russia) ; 1999 ; 185 p. (in Russian).

4. Danylevskyi M.F., Borysenko A.V., Polihun A.M., Sidelnikova L.F., Nesyn O.F. et al.

Terapevtychna stomatolohiia [Therapeutic Dentistry]. Kyiv : Zdorovia ; 2010 ; Vol. 2 : 407 p. (in Ukrainian).

5. Borysenko A.V. Karies zubov. Prakticheskoe rukovodstvo [Dental Caries. Practical Guide]. Kiev : Kniga-Plus ; 2000 : 342 p. (in Russian).

6. Borysenko A.V. (ed.)

Praktykum z terapevtychnoi stomatolohii [Workshop on Therapeutic Dentistry]. Kyiv : Knyha-Plus ; 2011 : 509 p. (in Ukrainian).

7. Langlais R.P. and Miller C.S. Atlas zabolevaniy polosti rta [Atlas of Oral Diseases]. Moscow : GEOTAR-Media ; 2008 : 80 p. (in Russian).

8. Lobanov C.A. Kak sokhranit zdorovye zuby. Profilaktika osnovnykh stomatologicheskikh zabolevaniy [How to Preserve Healthy Teeth. Prevention of Main Dental Diseases]. Sankt

Peterburg : Neva ; Moscow : OLMA-Press Ekslibris ; 2003 : 4157 (in Russian).

9. Serdiuk A.M. Medychni perspektyvy. 2007 ; 4 : 4-7. (in Ukrainian).

10. Berdnyk O.V., Zaikovska V.Yu., Sydorenko T.P. and Dobrianska O.V. Biomedical and Biosocial Anthropology. 2009 ; 2/13 : 12-14 (in Ukrainian).

Надійшла до редакції 12.12.2016 